\title{
An Analysis on Students' Substance Error in Writing Descriptive Texts
}

\author{
Supiani \\ Hamzanwadi University, Indonesia \\ Correspondence: Supiani, Hamzanwadi University, Indonesia. E-mail: supiani78@ gmail.com \\ Received: Februari 19, 2018 \\ doi: 10.29408/veles.v2i1.605.g428 \\ Accepted: Maret 21, 2018 \\ Online Published: April 1, 2018 \\ URL: http://dx.doi.org/10.29408/veles.v2i1.605.g428
}

\begin{abstract}
This study aims to describe students' substance errors especially the use of punctuation in writing descriptive texts. The present researcher used descriptive qualitative method in this study. It was conducted in English study program at the second semester of Hamzanwadi University. There were twenty students of $\mathrm{C}$ class chosen randomly to be participants. The data were collected by asking the participants to write an essay about descriptive text and asking the participants to fill some questionnaires. The participants' work sheets and the questionnaires were analyzed to find out the common errors in using punctuation. The analysis showed the most dominant error were (1) the students omitted the use of comma that was $37,77 \%$; (2) errors in using comma was $31,11 \%$; (3) error in using period that was $20 \%$; (4) students omitting period that was 6, 66\%; and (5) students omitted the use of apostrophe that was $4,44 \%$.
\end{abstract}

Keywords: Substance Errors, Descriptive Texts

\section{Introduction}

Language takes very important position when people want to express their opinion by mean of spoken or written. Sleeper (2007, p. 1) noted that language is a fundamental part of how humans interact with each other and the environment around them. Moreover, Brown (2006, p. 17) defines language as a system of arbitrary conventionalized vocal, written or gestural symbols that enable members of a given community to communicate intelligibly with one another. Principally, people use language to interact with other in their daily life. Hence, it is firm to be imagined how people can cooperate and make progression with the others without language. They will face some difficulties or obstacles.

Currently every country has been using a particular language as their national identity. They also choose a language as their first, second, or foreign language. In education, English is taught from the first year of junior high school up to the level of university. It is also regarded as a foreign language which is used not only in business domain but also in educational context in Indonesia.

In English there are four skills that every student should master; those are listening, speaking, reading and writing. Sholahudin (2013, p.13) stated that these four skills are related 
each other, listening skill of someone will influence their speaking, and reading skill will support someone's writing. This statement tells that a fluent speaker comes from a good listener, and then a professional writer comes from a great reader, so the students must comprehend the whole skills. One of the most difficult skills in English is writing skill. That is why teaching writing is considered as the most challenge thing to be taught. Moreover, writing skill deals with how to write some types of English such as recount, narrative, procedure, descriptive, news item, analytical exposition, hortatory exposition text. Whereas, the widest text using in human daily life is descriptive text.

Djuharie (2009, p. 153) stated that descriptive text is a type of text that aims to describe a person, a thing, a place, and an animal specifically. This text is taught in every level of education. As the matter of fact, in writing a text, students usually make an error particularly in arranging a descriptive text. As the proof, only some students can write well, just very little of them can use acceptable grammars, appropriate words, and correct punctuation. Most of them still lack of understanding how to create a good writing.

According to Ellis, as cited in Hasan (2008, p. 2) There is a strong belief that the errors in second of foreign language learning and acquisition are strongly influenced by their first language. This statement absolutely says the truth that is most of the error which is made by the students come from their habit when they write or pronounce their first language. The result, they cannot differ between how to arrange a sentence or a text in their first language and the foreign language.

Meanwhile, James (1998.129-161) noted that error in language learning divided into some level such as substance errors, text errors, lexical errors, classifying lexical errors, grammar errors, and discourse errors. While the basic mistake or error which is usually made by students in writing a text is that the use of punctuation. It is one kind of substance errors which is including into mechanics error. Punctuation consists of some marks which help the reader to understand what the writers mean in their writing, sentence by sentence or phrase to phrase. It means that error used of punctuation can change the meaning of particular sentences in a text. On the other hand, the students usually deny it especially in writing descriptive text.

Writing subject for students of English program is an obligation. It is taught from the second semester until the last semester. In fact there are many problems found, one example, they never think how to use punctuation well, and they just focus on what they are going to write while collecting some vocabularies which are related to the topic. That is why the present researcher wants to know more deeply by conducting a research which hopefully can help the English students to know their weaknesses especially in punctuation use.

\section{Method}

This research was categorized as a descriptive qualitative. Dantes (2012, p.51) stated that descriptive qualitative is a research that try to describe some phenomenon or events systematically and objectively. Here the present researcher tried to describe the error in using punctuation, when students of the second semester of English Study Program wrote a descriptive text. 


\subsection{Participants}

\subsubsection{Population}

The population of the study was the students of $\mathrm{C}$ class at the second semester of English Study Program Hamzanwadi University in the academic year 2016-2017.

\subsubsection{Sample}

The sample of the study was 20 students of C class chosen randomly. Moleong (2010, p. 223) said that in qualitative research choosing participant or sample should base on context of the study, in order to get much information the present researcher chose the students of second semester, because they were learning about descriptive text.

\subsection{Data Collection}

\subsubsection{Instrument of Collecting Data}

According to Sugiyono (2013, p.223) study which includes in qualitative research uses the researcher as the key instrument. In this case the researcher as the instrument had to be validated toward her understanding about qualitative research, the object of the study and how far her preparation in conducting the study. On the other hand Sugiyono (2013, p.223) said that after finding the focus of study the instrument can be improved by other instrument. Furthermore, the present researcher used questionnaire and writing task of descriptive text as other instruments.

\subsubsection{Techniques for Collecting Data}

The data were collected by asking the participants to write an essay about descriptive text. The next day the present researcher gave them a paper of questionnaire. Subsequently the present researcher analyzed the participants answer sheet, while checking theirs questionnaire. To have a trust result the present researcher conducted a small discussion with some people who master English rules well.

\subsection{Data Analysis}

The method of the analysis are: (1) Analyze students' answer sheet descriptively; (2) dentification, the present researcher identified the error of the students, while correcting them; (3) Interpretation of the data.

\section{Results}

Based on the errors appear, the present researcher classifies them as: (1) Punctuation Errors (Where the students make errors in using period and comma); (2) Omission (where students omit punctuation marks such as period, comma, apostrophes).

Referring to the numerous sums of errors, the present researcher will show the various kinds of errors below;

Table 1. Various Kinds of Students' Punctuation Errors

\begin{tabular}{lllll}
\hline No & Name & Wrong sentences & Correct sentences & Kind of errors \\
\hline 1 & B S & I have a friend, his name & $\begin{array}{l}\text { I have a friend. His } \\
\text { name is Rido. He is }\end{array}$ & Error of punctuation \\
& &
\end{tabular}


is Rido, he is from Sakra from Sakra.

Firstly, I would like

Firstly I would like to tell you... to tell you...

I like him very much

2 M. A S He never broke someone heart.

$\mathrm{H}$ someone's heart.

broke

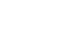

Student did not use the right punctuation that is period.

\section{Error of punctuation}

Student did not use the right punctuation that is comma.

Error of omission Student omitted the punctuation that is apostrophe.

I like him very much. Error of omission Student omitted the punctuation that is period.

When I have free time I When I have free always go... time, I always go...

Error of omission Student omitted the punctuation that is comma.

3 Kh A My friends call him My friends call him Error of punctuation Irham, he is from Irham. $\mathrm{He}$ is Kerongkong and he was fromKerongkong. He born on the... was born on the... The place is historic.

The place is historic

Student did not use the right punctuation that is period.

Error of omission Student omitted the punctuation that is period.

4 L R A Before you arrive to Gili Before you arrive to Error of omission Trawangan you have to Gili Trawangan, you Student omitted the look the... punctuation that is comma.

5 M. R A I have a partner, her name is Rabiah.

I have a partner. Her name is Rabiah.

She is very beautiful. but I She is very beautiful,

Error of punctuation

Student did not use the right punctuation that is period. 
don't have... $\quad$ but I don't have... Error of punctuation

Student did not use the right punctuation that is comma.

6 BQ. $\mathrm{H} \quad \ldots$ to tell you about my $\mathrm{N} \quad$ friend she is girl, her name is Ulfa.
... to tell you about my friend. She is a girl. Her name is Ulfa.

Error of punctuation and omission

Student did not use the right punctuation that is period, and she omitted the punctuation that is comma.

$\begin{array}{lll}7 & \mathrm{RZS} & \ldots \text { from him head, he has }\end{array}$ oval face.

... from his head. He Error of punctuation has oval face.

Student did not use the right punctuation that is period.

Error of omission He has white skin but he $\mathrm{He}$ has white skin, Student omitted the is... but he is... punctuation that is comma.

Error of omission Student omitted the In Mawun Beach you In Mawun Beach, punctuation that is can... you can... comma.

8 Ma I have a women friend, I have a woman she is my classmate... friend. She is my classmate...

Student did not use the right punctuation that is period.

9 Ir W If you come to visit the If you come to visit seger beach you will not... Seger Beach, you will not...

Error of omission Student omitted the punctuation that is comma.

10 L.S I I have friend, his name is khaerul his full name is Khaerul anam.

I have a friend. His name is Khaerul. His full name is Khaerul Anam.

... but one place
Error of punctuation

Student did not use the right punctuation that is period. 
... But one place make me interested, with panorama, there you can see beautiful feature

11 R A
She has big eyes. Flat nose. Bright skin, and tall body.

I think thats...
He did not want to live in boarding house because he...

After that he want to teach in a school.

If you want to go to Dagong Beach from Pancor. You will... make me interested that is panorama, you can see beautiful feature.

He doesn't want to Error of omission live in boarding Student omitted the house, because he... punctuation that is After that, he wants to teach in a school.

If you want to go to Dagong Beach from Pancor, you will...
Error of punctuation

Student did not use the right punctuation that is comma.
Error of omission Student omitted the punctuation that is comma.
Error of punctuation

Student did not use the right punctuation that is comma.

She has big eyes, flat Error of punctuation nose, bright skin, and tall body.

Student did not use the right punctuation that is comma.

I think that's...

Error of omission Student omitted the punctuation that is apostrophe.

Error of omission Student omitted the ... well because she talks to much in our class.

... well, because she talks too much in our class. punctuation that is comma.

Error of punctuation

... Lombok Timur. Exactly in Jerowaru subdistrict.

$13 \mathrm{Ja}$ I have a friend his name is
Student did not use the ... Lombok Timur, right punctuation that is exactly in Jerowaru comma. sub district.

is


Wahyu Santoso.

...very interesting because of...

14 R H The most mosques in Lombok have building of brick material. But not by the ancient mosque Rambitan.

15 N HW She live in her boarding house at Sanggeng, her hobby is Travelling.

Her future plan is she wanna be professional lecturer, and her dreams boy...

Green Corner is one of place to tourism, it is in Lombok Utara. ...very interesting, because of...

name is Wahyu Student omitted the Santoso. punctuation that is period.

Error of omission Student omitted the punctuation that is comma

Most mosques in Error of punctuation Lombok built of brick material, but it is not for the ancient mosque Rambitan.

She lives in her boarding house at Sanggeng. Her hobby is travelling.

Her future plan is she wants to be professional lecturer. Her dreams boy...

Green Corner is one of tourism place. It is in Lombok Utara

Student did not use the right punctuation that is comma.

Error of punctuation

Student did not use the right punctuation that is period.

Error of punctuation

Student did not use the right punctuation that is period.

Error of punctuation
Student did not use the right punctuation that is period

16 W S She is pretty smart, She is pretty, smar diligent, kind, and funny. diligent, kind, and funny.

She likes him because he is handsome, smart...

It is the famous tourism in Bogor, many visitor spend their time in it.

In this chance I would like
She likes him, because he is handsome, smart...

It is the famous tourism in Bogor. Many visitors spend Student did not use the their time there.
Error of omission Student omitted the punctuation that is comma.

Error of omission Student omitted the punctuation that is comma.

\section{Error of punctuation} right punctuation that is 
to talk about them.

Warm water is very nice water. Because if you swim there you don't need to use float.

Warm water is very nice water, because if you swim there, you don't need to use float.

In this chance, I Error of omission would like to talk Student omitted the about them.

17 Z M I have a partner, his name is Rojib Husnul.

The beach so compatible to fade your problem. Because the beach it's beauty.

18 M. Am In the class room she always attention to the lecturer...

In the summit you can make a tent to sleep at the night.

$19 \mathrm{Na} \mathrm{M}$ If I have gone home from kute beach. I always visited for buy something.

In the summit, you can make a tent to sleep at the night.

If I have back home from Kute Beach, I always something. buy name is Rojib Husnul.

The beach is so compatible to fade your problem, because the beach is beautiful.

In the class room, she always pays attention to the lecturer... punctuation that is comma.

Error of punctuation

Student did not use the right punctuation that is comma.

Error of punctuation

Student did not use the right punctuation that is period.

Error of punctuation

Student did not use the right punctuation that is comma.

Error of omission Student omitted the punctuation that is comma.

Error of omission Student omitted the punctuation that is comma.

Error of punctuation

Student did not use the right punctuation that is comma.

20 N U S The Watu Dodol beach is The Watu Dodol in. Banyuwangi, west beach is in java. Banyuwangi, west java.

The watu dodol beach

The watu dodol beach, is close by Bali Error of punctuation
Student did not need to use the punctuation that is period. 
crossing with bali island. island.

In addition we can enjoy In addition, we can the fresh air. enjoy the fresh air.
Student did not need to use the punctuation that is comma.

Error of omission Student omitted the punctuation that is comma.

The finding of the errors can be stabilized as follows:

Table 2. The Frequency of Errors

\begin{tabular}{llcc}
\hline No & Kind of errors & Total of error & Percentage \\
\hline 1 & Period & 9 & $20 \%$ \\
2 & Comma & 14 & $31,11 \%$ \\
3 & Omission (Period) & 3 & $6,66 \%$ \\
4 & Omission (Comma) & 17 & $37,77 \%$ \\
\hline 5 & Omission (Apostrophe) & 2 & $4,44 \%$ \\
& Total & \multicolumn{2}{c}{45} \\
\end{tabular}

\section{Discussion}

The finding research showed some important information that the students have different kinds of errors in using punctuation. Generally, from many kinds of punctuation marks, there are just three kinds of punctuation that were used by students namely period, comma, and apostrophe. It means the students made three errors in using them.

From the Table of frequency, the present researcher found that the most dominant errors of punctuation that is the students omit comma in making descriptive text. $37,77 \%$ is omitting comma. For-example "In addition we can enjoy the fresh air." The correct sentence was "In addition, we can enjoy the fresh air." There is comma after In addition.

Whereas, errors in using comma is $31,11 \%$. This showed how a small thing is usually denied by the students. For-example "I have a partner, his name is Rojib Husnul." The correct sentence was "I have a partner. His name is Rojib Husnul." There should be period after complete sentence. While $20 \%$ is error using period. For-example "... . But one place make me interested..." The correct sentence was “..., but one place make me interested..." Student should use comma before but, however the student put period. Whilst 6, 66\% is for omitting period. For-example "I like him very much" The right sentence was "I like him very much." There must be period after complete sentence. The lowest error is $4,44 \%$ for omitting apostrophe. For-example" He never broke someone heart." The right sentence was "He never 
broke someone's heart. Student didn't use apostrophe for showing possession. In addition, the questioners' result showed that most of the students sometimes confused between the use of full stop and comma.

\section{Conclusion}

In concluding, the students made a total 45 errors. The most dominant errors of punctuation marks that is $37,77 \%$ for omitting comma. $31,11 \%$ is errors using of comma. $20 \%$ is error using for period. 6, 66\% is omitting period. 4, $44 \%$ is omitting apostrophe. The result demands the lecturer to always give the students explanation about punctuation. On the other hand the students must learn more about it.

\section{References}

Brown, H. D. (2006). Principles of Language Learning and Teaching. New York: Pearson Education.

Dantes,Nyoman. (2012). Metode Penelitian. Yogyakarta: C.V Andi offset

Djuharie.Otong Setiawan. (2009). Teknik dan Panduan Menulis Melalui Explorasi Model Dan Latihan Essay Writing.Bandung.Irama Widya

Hasan. (2008). The Analysis of Grammatical Errors in Argumentative Writing; A Case Study at the Second Year Students of SMAN 1 Batukliang. Unpublished undergraduate thesis of Muhammadiyah University of Mataram Nusa Tenggara Barat, Indonesia

James, Carl. (1998). Error in Language Learning and Use Exploring Error Analiys. New York. Addison Wesley Longman Inc

Moleong,Lexi.J. (2010). Metode Penelitian Kualitative.Bandung. PT Remaja Rosdakarya

Sholahudin.M. (2013). Tutorial Writing Dalam Bahasa Inggris. Jogjakarta.Berlian

Sleeper, Amanda A. (2007). Speech and Language. New York. InfoBase publishing

Sugiyono.(2013). Metode Penelitian Kuantitatif Kualitatif dan R\&.Bandung:Alpabeta cv 